\title{
Prevention of adolescent sexual behavior: Can be with family counseling?
}

\author{
Frischa Meivilona Yendi
}

Universitas Negeri Padang

\begin{abstract}
Abstrak
One of the problems that arose in adolescence was juvenile delinquency. One form of juvenile delinquency is sexual behavior. The handling of sexual behavior in teenagers will not run smoothly if not supported by the parties around the life of youth, i.e. family. If there is one problem in the household, if it continues to be allowed to be dangerous. Settlement of problems in the family can be solved through counseling, which is family counseling.
\end{abstract}

Keyword: Perilaku seksual, konseling keluarga

\section{PENDAHULUAN}

Remaja merupakan suatu tahapan dimana individu mengalami transisi dari masa-masa kanak-kanak ke kehidupan dewasa. Semua remaja berada pada tahap kehidupan yang melibatkan pembelajaran cara-cara berpikir dan berperilaku baru agar dapat menghadapi berbagai kejadian secara adaptif. Pada tahap perkembangan ini, individu akan terus-menerus menemui berbagai tantangan atau permasalahan baru di sekolah, di rumah dan bersama teman sebayanya. Tantangan-tantangan baru akan sering melibatkan berbagai resiko bagi remaja, sehingga kemungkinan besar remaja akan bertindak dengan cara yang beresiko yang memperluas pengalaman hidupnya dengan bereksperimen dengan perilaku-perilaku baru. Setiap remaja adalah seorang individu dengan sikap, keyakinan, konstrak, perilaku dan respons uniknya masing-masing dalam menghadapi tantangan yang dihadapinya (Geldard, 2012) .

Banyak tantangan sulit yang dihadapi oleh para remaja menjadi pengalaman pertama kalinya dalam hidup mereka. Gregory (dalam Geldard, 2012) memaparkan bahwa tantangan yang secara umum dihadapi oleh remaja, yaitu remaja yang diresahkan oleh masalah seksual, bahkan kriminalitas, di kalangan remaja dapat tumbuh hingga ke tingkat mengancam jalinan sosial masyarakat. Permasalahan pada remaja adalah perilaku yang dipandang sebagai masalah dalam segi sosial, atau hal yang tidak sesuai dengan norma dan ketentuan orang dewasa (Jessor, Jessor, Jessor, \& Jessor, 1977; Nindya \& Margaretha, 2012).

Salah satu permasalahan yang muncul pada masa remaja adalah kenakalan remaja. Kenakalan remaja (juvenile deliquency) ialah anak-anak muda yang selalu melakukan kejahatan, dimotivasi untuk mendapatkan 
perhatian, status sosial dan penghargaan dari lingkungannya (Kartono, 2010). Dalam arti luas,kenakalan remaja adalah perbuatan/kejahatan/pelanggaran yang dilakukan oleh anak remaja yang bersifat melawan hukum, anti sosial, anti susila dan menyalahi norma-norma agama (Sudarsono, 2008).

Salah satu bentuk kenakalan remaja adalah perilaku seks bebas. Michael dkk (dalam Santrock, 2003) menjelaskan bahwa remaja belajar untuk mengaitkan hubungan seks dengan cinta. Sejumlah peneliti menemukan bahwa alasan utama remaja aktif melakukan tingkah laku seksual adalah karena jatuh cinta. Banyak di antara remaja yang tidak menyadari bahwa beberapa pengalaman yang tampaknya menyenangkan, justru menjerumuskan. Sebagaimana dikemukakan BKKBN (2007) bahwa dari 64 juta jumlah remaja di Indonesia, sekitar 1 juta remaja laki-laki (5\%) dan 200 ribu remaja perempuan (1\%) menyatakan secara terbuka bahwa mereka pernah melakukan hubungan seksual yang dilakukan sebelum menikah.

\section{PEMBAHASAN}

Menurut WHO, kehamilan remaja adalah kehamilan yang berlaku pada wanita yang berusia 11-19 tahun. Dalam beberapa dekade terakhir ini, kehamilan remaja telah menjadi masalah kesehatan yang penting tidak hanya di kalangan remaja tetapi juga di sejumlah besar negara maju dan berkembang. Kehamilan di usia remaja adalah bukan sebuah fenomena baru. Hal ini karena masyarakat secara global misalnyaAsia Selatan, Timur Tengah dan Afrika Utara mengikuti tradisi menikah pada usia muda secara turun-temurun (Melfira \& Susanti, 2018).

Australian National University (ANU) bersama Pusat Penelitian Kesehatan Universitas Indonesia (UI) tahun 2010/2011 juga melakukan penelitian terhadap 3.006 remaja dalam penelitian di Jakarta, Tangerang dan Bekasi didapatkan hasil sebesar 20,9 persen remaja usia 17-24 tahun hamil sebelum menikah dan 38,7 persen remaja mengalami kehamilan sebelum menikah dan kelahiran setelah menikah (Asmara, 2016). Kasus kehamilan tidak diinginkan di Kota Yogyakarta juga cukup tinggi. Sepanjang tahun 2013 terdapat 325 kasus kehamilan tidak diinginkan (Purbanova, Demartoto,\& Murti, 2017).

Di Kalimantan Barat, perilaku seks pra nikah bukan menjadi suatu hal yang tabu di kalangan remaja SMA, dari tingkat Kabupaten Kota hingga daerah seks pranikah sudah menjadi konsumsi remaja, hingga kini jika dipersentasekan jumlah remaja yang telah melakukan seks pranikah berjumlah $67,30 \%$ angka tersebut sangat mengejutkan PKBI. Permasalahan remaja merupakan permasalahan yang sangat kompleks, salah satunya adalah seks bebas. Seks bebas merupakan hubungan yang didorong oleh hasrat seksual, baik dengan lawan jenis maupun sesama jenis, tanpa adanya ikatan perkawinan, dan dapat dilakukan secara bebas dengan banyak orang (Putri, Dasuki, \& Wahyuni, 2015). Perilaku seksual dan pacaran berkaitan erat satu sama lain, karena pacaran akan menghadapkan remaja dengan kondisi yang meningkatkan pengalaman seksual mereka (SDKI dalam Wijaya, 2015).

Hasil survei Dinas Kesehatan Provinsi Aceh tahun 2012, Kota Lhokseumawe menduduki peringkat pertama terbanyak pelaku seks pranikah di kalangan pelajar, yaitu 70\%, kemudian ditempat kedua menyusul kota Banda Aceh sebanyak 50\% dari kasus perilaku seks pranikah diseluruh Provinsi Aceh. Hasil Survei Kesehatan Remaja tahun 2012 oleh Badan Pemberdayaan Perempuan dan Perlindungan Anak (BP3A) Aceh menunjukkan 12\% mahasiswa pernah terlibat seks bebas, 6,42\% pelajar SMA di Kota Banda Aceh pernah terlibat seks bebas, $1,82 \%$ pelajar mengaku sudah pernah tidur bersama, dan $14,72 \%$ pelajar pernah ciuman dan pelukan (Kasim, 2014).

Seperti penelitian Cahyo (2009) terhadap remaja di Gandekan Lor juga menyatakan bahwa kenakalan yang sering terjadi salah satunya MBA (Married By Accident), salah satu faktor penyebabnya adalah ketidakberfungsian sosial peran orang tua dalam keluarga. Kondisi sosial telah menyebabkan kontrol orang tua terhadap remaja semakin berkurang, sehingga banyak terjadi kelabilan dalam berbagai sektor di lingkungan keluarga. Lemahnya kontrol keluarga mengakibatkan remaja menjadi nakal tidak terkontrol dan tidak terkendali. Semakin menurunnya kontrol orang tua terhadap remaja meningkatkan nafsu kepentingan diri sendiri dan meningkatkan jumlah remaja dengan perilaku nakal (Kartono, 2013).

Penanganan terhadap perilaku seks bebas pada remaja yang diusahakan oleh Pemerintah tidak akan berjalan lancar apabila tidak didukung oleh pihak-pihak yang berada di sekitar kehidupan remaja, yaitu keluarga. Keluarga merupakan lingkungan pertama dan utama dalam membentuk watak dan kepribadian anak, melalui lingkungan keluarga, anak memperoleh pendidikan pertama untuk menumbuhkembangkan potensinya. Kartono (1997) menjelaskan bahwa salah satu kewajiban dan hak utama orangtua tidak dapat dipindahkan adalah mendidik anak-anaknya. 
Penelitian yang dilakukan Rimporok (2015), komunikasi dalam keluarga untuk mencegah kenakalan serta membina anak usia remaja menunjukan bahwa dalam rangka pendidikan dan pembinaananak untuk meminimalisir kenakalan remaja di desa Maumbi kecamatan Kalawat Kabupaten Minahasa Utara ternyata sangat sangat penting karena hampir semua responden menjawabnya pertanyaan cenderung ke arah yang positif.

Untuk mencegah permasalahan yang terjadi dikalangan remaja perlu adanya suatu carapenyampaian informasi tentang bahaya-bahaya dari sebuah dampak pergaulan bebas. Untuk mendapatkan informasi tersebut peran sekolah dan keluarga sangatlah penting dibutuhkan untuk pemberian informasi. Keluarga berfungsi dengan baik jika remaja mempersepsi positif dalam keluarganya terdapat pembagian tugas yang jelas dan semua anggota keluarga dapat melaksanakan tanggung jawabnya dengan baik sehingga remaja akan belajar untuk bertanggung jawab pada dirinya sendiri (Rochmah\& Rochmah, 2005). Jika lingkungan keluarga cukup kondusif, maka remaja cenderung dapat mencapai kematangan emosionalnya. Sebaliknya, jika remaja kurang dipersiapkan untuk memahami peran-perannya maka akan menimbulkan ketidaknyamanan emosionalnya sehingga apabila emosional remaja tidak terkontrol akan terjadi hal-hal kearah yang negatif.

Anak merupakan salah satu aset bangsa yang harus dijaga dan dilindungi. Undang-undang No.23 Tahun 2002 tentang Perlindungan Anak, Pasal 1 Ayat 2 berbunyi: "Perlindungan anak adalah segala kegiatan untuk menjamin dan melindungi anak dan hak-haknya agar dapat hidup, tumbuh, berkembang, dan berpartisipasi, secara optimal sesuai dengan harkat dan martabat kemanusiaan, serta mendapat perlindungan dari kekerasan dan diskriminasi (Huraerah, 2018). Di era millenial seperti ini, seorang anak harus dididik dengan baik, agar menjadi generasi penerus bangsa yang hebat dan berakhlak. Mendidik anak merupakan tanggung jawab dari keluarga terutama peran ayah dan ibu. Adapun peran orangtua dalam mendidik anak seperti mengajarkan tentang pendidikan seks sejak dini, rasa tanggung jawab, berakhlak baik, saling mengasihi, mengawasi pergaulan anak, dan memberi perhatian dan kasih sayang kepada anak.

Minuchin (dalam Willis, 2011) keluarga adalah satu kesatuan (entity) suatu sistem atau suatu organisme. Keluarga bukanlah merupakan kumpulan (collection) atau penjumlahan (a sum total) dari individu-individu. Ibarat amuba, keluarga mempunyai komponen-komponen yang membentuk organisme keluarga itu. Komponenkomponen itu adalah anggota keluarga. Fungsi sistem keluarga yaitu saling membantu dan membuat mandiri anggota keluarga. Jadi, apabila ada salah satu dari komponen keluarga yang terganggu atau tidak berfungsi, maka akan menyebabkan sistem keluarga terganggu. Hal ini karena terdapat kehidupan emosional dan informal dalam keluarga. Apabila ada salah satu permasalahan dalam rumah tangga, jika terus dibiarkan akan berbahaya. Permasalahan yang terjadi harus segera menemukan solusi terbaik sehingga tidak timbul dampak negatif bagi keluarga. Penyelesaian permasalahan dalam keluarga dapat diselesaikan melalui konseling yaitu konseling keluarga.

Menurut Golden dan Sherwood (dalam Latipun, 2001) konseling keluarga adalah metode yang dirancang dan difokuskan pada keluarga dalam usaha untuk membantu memecahkan masalah perilaku klien. Sehingga konseling keluarga merupakan proses bantuan yang diberikan kepada individu anggota keluarga dalam memecahkan masalah keluarga yang dihadapinya. Dalam hal ini, perilaku klien dalam keluarga dapat diubah dengan menggunakan pendekatan behavior therapy (terapi tingkah laku). Menurut Corey (2009) terapi tingkah laku adalah penerapan aneka ragam teknik dan prosedur yang berakar pada berbagai teori tentang belajar. Terapi ini menyertakan penerapan yang sistematis prinsip-prinsip belajar pada pengubahan tingkah laku ke arah caracara yang lebih adaptif. Jadi, terapi perilaku merupakan pengubahan perilaku lama dan diganti menggunakan perilaku baru yang lebih baik lagi, sehingga perilaku sang anak dapat diubah menggunakan behavior therapy dengan melibatkan anggota keluarganya.

\section{KESIMPULAN}

Penanganan terhadap perilaku seks bebas pada remaja yang diusahakan oleh Pemerintah tidak akan berjalan lancar apabila tidak didukung oleh pihak-pihak yang berada di sekitar kehidupan remaja, yaitu keluarga. Keluarga merupakan lingkungan pertama dan utama dalam membentuk watak dan kepribadian anak, melalui lingkungan keluarga, anak memperoleh pendidikan pertama untuk menumbuhkembangkan potensinya. Salah satu kewajiban dan hak utama orangtua tidak dapat dipindahkan adalah mendidik anak-anaknya.Apabila ada salah satu permasalahan dalam rumah tangga, jika terus dibiarkan akan berbahaya. Permasalahan yang terjadi harus segera menemukan solusi terbaik sehingga tidak timbul dampak negatif bagi keluarga. Penyelesaian permasalahan dalam keluarga dapat diselesaikan melalui konseling yaitu konseling keluarga. 


\section{DAFTAR RUJUKAN}

Asmara, D. A. (2016). Faktor-faktor yang berhubungan dengan perilaku seksual pranikah beresiko kehamilan tidak diinginkan pada mahasiswa yang bertempat tinggal di kos "LAS VEGAS"(Studi Kasus pada Universitas X di Kota Semarang) (Doctoral dissertation, Universitas Negeri Semarang).

BkkbN, R. I. (2007). Hindari Kehamilan “4 Terlalu”.

Cahyo, R. N. (2009). Skripsi: keluarga dan kenakalan remaja (studi tentang penyimpangan perilaku remaja di kampung Gandekan Lor Yokyakarta). Diperoleh pada tanggal, 6.

Corey, G. (2009). Teori dan praktek konseling dan psikoterapi. Bandung: PT Refika Aditama.

Geldard, K. (2012). Konseling Remaja Intervensi Praktis Bagi Remaja Berisiko. Yogyakarta: Pustaka Pelajar.

Huraerah, A. (2018). Kekerasan terhadap anak. Nuansa Cendekia.

Jessor, R., Jessor, S., Jessor, S. L., \& Jessor, R. (1977). Problem behavior and psychosocial development: A longitudinal study of youth.

Kartono, K. (1997). Psikologi Wanita (1) Gadis Remaja dan Wanita-wanita.

Kartono, K. (2010). Kenakalan remaja. Jakarta: PT Raja Grafindo Persada.

Kartono, K. (2013). Patologi Sosial Jilid I, cet ke 13.

Kasim, F. (2014). Dampak Perilaku Seks Berisiko Terhadap Kesehatan Reproduksi Dan Upaya Penanganannya (Studi Tentang Perilaku Seks Berisiko Pada Usia Muda Di Aceh). Jurnal Studi Pemuda, 3(1), 39-48.

Latipun. (2001). Psikologi konseling (edisi ketiga). Malang: UMM University Press.

Melfira, E. J., \& Susanti, S. S. (2018). Fungsi keluarga dalam pencegahan kehamilan remaja. Jurnal Ilmiah Mahasiswa Fakultas Keperawatan, 3(3).

Nindya, P. N., \& Margaretha, R. (2012). Hubungan antara kekerasan emosional pada anak terhadap kecenderungan kenakalan remaja. Jurnal Psikologi Klinis dan Kesehatan Mental, 1(02), 1-9.

Purbanova, R., Demartoto, A., \& Murti, B. (2017). Social Development of Children Under-Five as the Impact of Extramarital Pregnancy. Journal of Maternal and Child Health, 2(3), 213-222.

Putri, N. T., Dasuki, D., \& Wahyuni, B. (2015). Hubungan komunikasi interpersonal orang tua dengan perilaku seksual pranikah remaja di kota padang. Jurnal Kesehatan Reproduksi, 3(2), 117-129.

Rimporok, P. B. (2015). Intensitas Komunikasi dalam Keluarga Untuk Meminimalisir Kenakalan Remaja Di Desa Maumbi Kecamatan Kalawat Kabupaten Minahasa Utara. ACTA DIURNA KOMUNIKASI, 4(1).

Rochmah, E. Y., \& Rochmah, E. Y. (2005). Psikologi perkembangan.

Santrock, J. W. (2003). Adolescence perkembangan remaja. Jakarta: Erlangga, 422-4.

Sofyan, S. W. (2011). Konseling keluarga. Bandung: Alfabeta.

Sudarsono. (2008). Kenakalan Remaja. Jakarta: PT. Rineka Cipta

Undang-Undang, R. I. (2003). No. 23 Tahun 2002 tentang Perlindungan Anak. Jakarta: Sekretariat Negara RI.

Wijaya, E. C. (2015). Akses informasi, tingkat pengetahuan kesehatan reproduksi dan perilaku seksual pranikah pada remaja di indonesia (analisis lanjut data sdki 2012). 